\title{
MEMBANGUN MEDIA PROMOSI DENGAN KARAKTER ANIMASI 3D
}

\author{
Po. Abas Sunarya ${ }^{1}$ \\ Bayu Porsea Yudha ${ }^{2}$ \\ Andi Nugroho ${ }^{3}$ \\ e-mail:abas@raharja.info; bayuporsea@raharja.info; andi.nugroho@raharja.info;
}

\begin{abstract}
ABSTRAK
Perkembangan media komunikasi visual pada saat ini sangat membantu dalam menunjang informasi dan komunikasi.Namun seringkali media komunikasi visual yang disajikan kurang efektif dan tepat guna.Dengan media Animasi 3D, media animasi 3D dianggap cukup efektif untuk menarik minat costumer, karena animasi 3D cukup di gemari semua kalangan. Penyajian media iklan yang menarik dan menghibur akan mendorong masyarakat luas untuk mengetahui lebih detail dan memiliki minat untuk bergabung dalam suatu perusahaan atau lembaga tersebut. Hal ini bukti bahwa perancangan suatu karya seni meningkat sehingga dapat mengikuti perkembangan teknologi yang begitu pesat.PT. Movio Screen sebagai perusahaan yang bergerak dibidang industri creative dinilai perlu memiliki sebuah produk yang menarik dan dapat menjadi media informasi serta media promosi khususnya bagi para konsumen.Karena kebutuhan tersebut maka dalam jurnal ini mengangkat permasalahan menjadi topik permasalahan. Diharapkan animasi serial ini bermanfaat bagi PT. Movio Screen khususnya untuk calon customer, klien, dan masyarakat.
\end{abstract}

Kata Kunci: Media Promosi, Citra, informasi,

\section{ABSTRACT}

The development of visual communication media at this time is very helpful in supporting the information and communication. But often presented visual communication media are less effective and appropriate. With media 3D Animation, 3D animation media considered effective enough to attract the customer, because $3 D$ animated enough to enjoy doing all circles. Media presentation of interesting and entertaining ads will encourage the general public to know more detail and have an interest to join a company or institution. It is evidence that the design of an artwork increased so as to keep up with technology that is so rapidly. PT. Screen Movio as a company engaged in the creative industries is considered necessary to have a product that is attractive and can be a medium of information and media campaign, especially for consumers. Because of that need, so in this journal issue raised the issue became a topic. This animated series is expected to be useful for PT. Movio Screen especially for prospective customers, clients, and communities

Keywords: Media Promotion, image, information

\section{PENDAHULUAN}

Perkembangan teknologi saat ini sudah sangat maju, kemampuan dalam hal teoritis di bidang komputer saja belum tentu cukup untuk mengikuti perkembangan zaman tersebut, dan sampai saat ini terdapat terobosan-terobosan baru dimana komputer menjadi hal yang tidak terpisahkan dari kebutuhan sehari-hari sehingga membuat integrasi antar 
berbagai disiplin ilmu seperti animasi, broadcasting dan audio-visual. Ditandai dengan munculnya berbagai macam bentuk karya seni yang menggunakan aplikasi komputer sebagai sarana perencanaan dan perancangan sebuah karya, contohnya: film dokumenter, profile film feature biografi seseorang, iklan, Animasi dan berbagai bentuk rancangan komunikasi visual lainnnya. Hal ini dibuktikan bahwa perancangan suatu karya seni meningkat lebih baik, sehingga dapat mengikuti tuntutan perkembangan teknologi yang begitu pesat.

Sarana multimedia dan Animasi sebagai alat komunikasi dan promosi mempunyai peranan yang sangat penting dalam menginformasikan sesuatu kepada masyarakat, hal ini dinilai sangat komunikatif dan efektif disaat mobilitas manusia yang semakin tinggi sehingga dibutuhkan bentuk media komunikasi dan promosi yang menarik dan lebih interaktif yang ditujukan kepada masyarakat, dan banyak cara untuk menyampaikan suatu informasi yang diolah ke dalam bentuk multimedia dan animasi agar terlihat lebih menarik dalam penyampaiannya.Perkembangan

media komunikasi visual pada saat ini sangat membantu dalam menunjang informasi dan komunikasi.Namun seringkali media komunikasi visual yang disajikan kurang efektif dan tepat guna Dengan media Animasi 3D, karena animasi 3D cukup di gemari semua kalangan. Animasi 3d yang akan di buat berupa serial komedi dengan 2 tokoh karakter yang menceritakan tentang persahabatan bertema komedi dengan alat-alat tradisional Indonesia yang berdurasi 34 menit.yang akan di implementasikan pada website PT.Movio Screen dan youtube.

\section{PERMASALAHAN}

Dalam kasus ini, Pentingnya media promosi dengan design karakter animasi 3d, Antara lain untuk untuk menarik perhatian dan menunjang promosi pada PT. Movio Screen. Di karenakan ketatnya persaingan di bidang perusahaan desain animasi grafis, Maka dari itu dalam pembahasan ini akan membahas tentang kegiatan promosi pada PT. Movio Screen. Dan Manfaat seperti apa yang akan di capai melalui animasi serial dalam bentuk animasi 3D, Namun seringkali media komunikasi visual yang disajikan kurang efektif dan tepat guna, dimana efektifkah media promosi berupa Media Komunikasi Visual hingga berapa besar tingkat keefektifan Media Komunikasi Visual dalam mempromosikan PT tersebut dalam menggunakan animasi 3D dalam mempromosikan perusahaan tersebut ke khalayak.

\section{TINJAUAN PUSTAKA}

\section{Media Komunikasi Visual}

Menurut Maimunah dkk (2012:284) [9] "Media adalah sarana untuk menyampaikan pesan atau informasi kepada public dengan menggunakan berbagai unsur komunikasi grafis seperti teks atau gambar atau foto. Media adalah saluran penyimpanan pesan komersial kepada khalayak sasaran atau dapat dikatakan salah satu komunikasi periklanan yang dilakukan melalui saluran media tertentu, seperti televisi, surat kabar, majalah, radio, 
internet, buku profil, media luar ruangan, iklan transit dan direct mail. Komunikasi visual (komunikasi melalui penglihatan) menurut wikipedia adalah sebuah rangkaian proses penyampaian infromasi atau pesan kepada pihak lain dengan penggunaan media penggambaran yang hanya terbaca oleh indera penglihatan. Komunikasi visual menkombinasikan seni, lambang, tipografi, gambar, desain grafis, ilustrasi, dan warna dalam penyampaiannya.Media Komunikasi Visual adalah sarana untuk penyampaian pesan atau informasi kepada publik yang dirangkai dengan penggunaan media penggambaran yang hanya dapat terbaca oleh indera penglihatan.

\section{Pengertian Promosi}

Menurut Dewi Immaniar dkk (2014:425).[6] Promosi adalah tindakan menginformasikan atau meningkatkan konsumen tentang spesifikasi produk atau merek. Promosi mempunyai kekuatan untuk menyampaikan pesan, dan diperlukan perancangan khusus agar promosi tersebut memiliki visual yang kuat dan menciptakan keserasian didalam rangkaian pemasaran, karena promosi adalah berkaitan langsung dalam upaya untuk memperkenalkan produk kepada konsumen dengan memikat hati mereka melalui pemberian kesankesan baik, yang mampu diingat dan dirasakan oleh konsumen. Pada hakikatnya promosi adalah suatu bentuk komunikasi pemasaran.Yang dimaksud dengan komunikasi pemasaran adalah aktivitas pemasaran yang berusaha menyebarkan informasi, mempengaruhi atau membujuk dan mengingatkan pasar sasaran atas perusahaan dan produknya agar bersedia menerima dan loyal pada produk yang ditawarkan perusahaan yang bersangkutan.

\section{Pengertian Animasi}

Pengertian AnimasiMenurut Ibiz Fernandes animasi definisikan "Animation is the process of recording and playing back a sequence of stills to achieve the illusion of continues motion" ( Ibiz Fernandez McGraw- Hill/Osborn, California, 2002) [3]

Yang artinya kurang lebih adalah "Animasi adalah sebuah proses merekam dan memainkan kembali serangkaian gambar statis untuk mendapatkan sebuah ilusi pergerakan." Berdasarkan arti harfiah, Animasi adalah menghidupkan.Yaitu usaha untuk menggerakkan sesuatu yang tidak bisa bergerak sendiri.Secara garis besar, animasi computer dibagi menjadi dua kategori, adalah sebagai berikut a).Computer Assisted Animation, animasi pada kategori ini biasanya menunjuk pada system animasi 2 dimensi, yaitu mengkomputerisasi proses animasi tradisional yang menggunakan gambaran tangan. Computer digunakan untuk pewarnaan, penerapan virtual kamera dan penataan data yang digunakan dalam sebuah animasi.b.)Computer Generated Animation, pada kategori ini biasanya digunakan untuk animasi 3 dimensi dengan program 3D seperti 3D Studio Max, Maya, Autocad dll. Animasi merupakan salah satu bentuk visual bergerak yang dapat dimanfaatkan untuk menjelaskan 
materi pelajaran yang sulit disampaikan secara konvensional. Dengan diintergrasikan ke media lain seperti video, presentasi, atau sebagai bahan ajar tersendiri animasi cocok untuk menjelaskan materi-materi pelajaran yang secara langsung sulit dihadirkan di kelas atau disampaikan dalam bentuk buku. Sebagai misal proses bekerjanya mesin mobil atau proses terjadinya tsunami.

Menurut (Djalle, Zaharuddin. Purwantoro, Edi. Dasmana, Demi. 2010. 3D Animation Using 3D StudioMax. Bandung: Penerbit Informatika Bandung) [2] Definisi animasi sendiri berasal dari kata 'to animate' yang berarti menggerakkan, menghidupkan.Misalkan sebuah benda yang mati, lalu digerakkan melalui perubahan sedikit demi sedikit dan teratur sehingga memberikan kesan hidup. Animasi adalah proses penciptaan efek gerak atau efek perubahan bentuk yang terjadi selama beberapa waktu. Animasi juga merupakan suatu teknik menampilkan gambar berurut sedemikian rupa sehingga penonton merasakan adanya ilustrasi gerakan (motion) pada gambar yang ditampilkan.Definisi tersebut mengartikan bahwa bendabenda mati dapat 'dihidupkan'.Pengertian tersebut hanyalah merupakan istilah yang memiripkan, dalam arti tidak harus diterjemahkan secara denotatif, melainkan simbol yang menyatakan unsur kedekatan.

Sedangkan Animasi 3D sendiri mengandung pengertian menurut (Djalle, Zaharuddin. Purwantoro, Edi. Dasmana, Demi. 2010. 3D Animation Using 3DStudioMax. Bandung:
Penerbit Informatika Bandung) Animasi 3D merupakan animasi yang dibuat dengan menggunakan model seperti yang berasal dari lilin, clay, boneka/marionette dan menggunakan kamera animasi yang dapat merekam frame demi frame. Ketika gambargambar tersebut diproyeksikan secara berurutan dan cepat, lilin atau clay boneka atau marionette tersebut akan teihat seperti hidup dan bergerak. Animasi 3D dapat juga dibuat dengan menggunakan komputer. Proses awalnya adalah membentuk model, pemberian tekstur, warna, hingga cahaya. Kemudian model tersebut diberi kerangka, warna, hingga cahaya.Kemudian model tersebut diberi kerangka dan gerakanya dirancang satu persatu. Seluruh proses pembuatannya dari awal hingga akhir dikerjakan di komputer contohnya film animasinya Walt Disney atau Pixar semacam Shrek, Aladin, The Cars atau Final Fantasy.

\section{Penggunaan Animasi Film}

Penggunaan animasi film tidak terbatas hanya untuk film-film bagi anak- anak atau film hiburan, tetapi juga dipergunakan diberbagai bidang, karena disisi lain animasi dapat menerangkan dengan rinci sesuatu hal atau informasi yang ingi disampaikan kepada masyarakat. Berikut ini adalah 5 contoh penggunaan animasi film : a). Animasi Forensik adalah Animasi dibuat untuk menerangkan terjadinya kecelakaan, berdasarkan saksi mata, data-dat hasil testing kendaraan; b). Animasi Simulasi adalah Animasi ini digunakakn ntuk membantu menggambarkan proses terjadinya sesuatu kejadian atau apa yang akan dihadapi, atau bagaimana sesuatu hal akan terjadi biasa dikenal juga dengan 
Infographic Animation.c. Animasi untuk Arsitektur

Penggunaan animasi untuk bidang arsitektur akan membantu, misalnya untuk menggambarkan struktur suatu gedung baik gedung bertingkat sejak awal perencanaan, proses pembangunan hingga selesai, dan tidak hanya pada gedung bertingkat saja, tetapi juga untuk memperlihatkan interior dengan berbagai kemungkinan perubahan warna dinding serta tata perlengkapannya, juga dapat memperlihatkan bentuk irisan dan potongan melintang yang diperlukan.

a. Animasi untuk pendidikan

Berguna untuk memperjelaskan tentang koordinasi gerak, dimana dalam satu gerakan badan diperlihatkan gerakan tulang-tulang serta sendi tertentu serta hubungannya dengan gerak otot, yang mana otot yang meregang serta otot mana yang melakukan gerakan menarik.

b. Animasi untuk hiburan dan komersial

Saat ini begitu banyak film animasi yang dibuat tidak hanya untuk anakanak saja, tetapi juga untuk masyarakat luas dimana dapat diciptakan karakter- karaker menarik, yang masing-masing memiliki watak sendiri-sendiri seolah- olah demikianlah hidup ini, juga untuk menciptakan khayalan-khayalan untuk memperkuat visualisasi suatu adegan, dan seringkali digunakan juga untuk keperluan iklan di televisis (TVCommercial).

\section{Tujuan Promosi}

Menurut Fandy Tjiptono (2008: 221) [14] "Tujuan Utama dari promosi adalah menginformasikan, mempengaruhi dan membujuk, serta mengingatkan pelanggan sasaran tentang perusahaan dan bauran pemasarannya".

\section{Bentuk Promosi}

Menurut Dewi Immaniar (2014:425426) [3] Beberapa tugas khusus itu sering disebut bentuk promosi, antara lain :a). Personal Selling, adalah komunikasi langsung (tatap muka) antara penjual dan calon pelanggan untuk memperkenalkan suatu produk kepada calon pelanggan dan membentuk pemahaman pelanggan terhadap produk sehingga mereka akan mencoba dan membelinya; b). Mass Selling, adalah pendekatan yang menggunakan media komunikasi untuk menyampaikan informasi kepada khalayak ramai dalam satu waktu. Metode ini memang tidak sefleksibel personal selling, namun merupakan alternatif yang lebih murah untuk menyampaikan informasi ke khalayak (pasar sasaran) yang jumlahnya sangat banyak dan tersebar luas; c). Promosi Penjualan, adalah bentuk persuasi langsung melalui penggunaan berbagai insentif yang dapat diatur untuk merangsang pembelian produk dengan segera atau meningkatkan jumlah barang yang dibeli pelanggan; d). PublicRelations (Hubungan Masyarakat), adalah upaya komunikasi menyeluruh dari suatu perusahaan untuk mempengaruhi persepsi, opini, keyakinan dan sikap berbagai orang yang terlibat, mempunyai kepentingan dan dapat mempengaruhi kemampuan 
perusahaan dalam mencapai tujuannya; e). Direct Marketing (Pemasaran Langsung), adalah sistem pemasaran yang bersifat interatif, yang memanfaatkan satu atau beberapa media iklan untuk menimbulkan respon yang terukur atau tranksaksi di sembarang lokasi.Umumnya bentukbentuk promosi memiliki fungsi yang sama, hanya saja dapat dibedakan berdasarkan tugas-tugas khususnya

\section{Literature Review}

1. Penelitian yang dilakukan oleh Apriliana Indah Paramitha berjudul "KISAH AYU INTAN PERMANI" [7 ]Film kartun merupakan serangkaian gambar yang bergerak hingga menyerupai gambar hidup. Tentu ini adalah suatu hal yang istimewa dan mengagumkan. Maraknya film kartun yang berkembang saat ini tidak diimbangi dengan pembuatan film kartun. Perkembangan film kartun 3D di Indonesia masih sangat lemah. Mungkin karena pembuatannya yang memakan waktu yang lama. Dan diaya yang besar untuk memproduksinya. Sehingga dengan minimnya pembuatan film animasi 3D di Indonesia, maka pada penelitian ini dijelaskan tentang cara pembuatan suatu film animasi pendek dari awal sampai akhir. Film pendek animasi 3D ini berjudul Kisah Ayu Intan Permani. Dibuat menggunakan perangkat lunak utama iClone V5.4. Metode pengembangan sitem yang digunakan dalam pembuatan film pendek animasi 3D ini adalah MDLC. Pembuatan film animasi pendek ini menceritakan tentang seorang pembantu yang berniat ingin melamar putri dari majikannya. Tapi sang majikan bersih keras tidak mau anaknya berteman dan dekat dengan pembantu. Dan akhirnya pembantu itu pun kabur dengan sang putri. kesimpulan : Animasi Kisah Ayu Intan Permani hanya menyajikan sebuah ceria mengenai perjalanan cinta seorang perempuan yang cintanya tidak direstui oleh orang tuanya. Maka diharapkan kepada peneliti selanjutnya untuk membuat film animasi yang mampu memberikan manfaat bagi orang lain dan memberikan contoh yang lebih baik bagi orang yang melihatnya. Cerita film animasi ini masih sangat sederhana dan dimungkinkan untuk dikembangkan lagi sehingga akan menghasilkan film animasi yang lebih baik dan lebih mempunyai banyak manfaat.

2. Penelitian yang dilakukan oleh Moch Adhi Nugraha berjudul "PERANCANGAN PROSEDUR KKP DAN TA/SKRIPSI DENGAN MENGGUNAKAN MEDIA AUDIO VISUAL PADA PERGURUAN TINGGI RAHARJA"[10]. Saat ini, Prosedur KKP, TA/Skripsi hanya berupa buku pedoman yang diberikan kepada mahasiswa/i, namun didalam prosesnya sering terjadi keterlambatan cetak buku panduan KKP, TA/Skripsi yang akan di terima oleh mahasiswa, sehingga KKP, TA/Skripsi sudah berjalan namun mahasiswa belum mendapat acuan yang pasti dalam membuat laporan KKP, TA/Skripsi. Selain itu dengan tampilan Animasi akan lebih menarik, dan membantu kebutukan mahasiswa dalam memperoleh informasi detail dan up to date yang diberikan dari pihak akademik. Kesimpulan : Dari hasil analisa yang telah dilakukan, maka dapat di simpulkan, agar lebih 
memperkaya dari unsur-unsur elemen pendukung dari media yang sudah ada, dimana aspek-aspek visualnya seperti aspek citra, aspek tampilan, aspek identitas dan aspek visual lainya disesuaikan dengan image Perguruan Tinggi Raharja yang berbasis komputerisasi dan disesuaikan dengan perkembangan tiap tahunnya

3. Sedangkan penelitian yang dilakukan Beatrice Waskita, berjudul FILM

\section{ANIMASI} "PENDAFTARAN

MAHASISWA BARU" MENGGUNAKAN 3DS MAX :ANIMATION EFFECTS, LIGHTNING, AND SHOOTING. [15]. Penulisan ini akan membahas tentang pembuatan Film Animasi Pendaftaran Calon Mahasiswa pada Universitas Gunadrama, dengan tata cara jalur Regional dan jalur Beasiswa, dengan menggunakan datadata yang tersedia pada ajaran semester genap tahun 2007/2008. Namun, pembahasannya dibatasi pada bagaimana membuat animation effects, lightning, dan shooting. Implementasi animasi ini dibuat dengan menggunakan perangkat lunak utama yaitu 3DS Max 9. Sedangkan perangkat lunak pendukung yang digunakan adalah Adobe Photoshop CS kesimpulan : Pembuatan aplikasi film animasi pendaftaran calon mahasiswa di Universitas Gunadarma diharapkan mampu memberikan informasi jalur pendaftaran untuk masyarakat umum yang akan melakukan pendaftaran di Universitas Gunadarma dengan menarik. Selain memberikan informasi, film animasi ini berfungsi untuk memberikan kemudahan dengan memberikan gambaran mengenai tata cara pendaftaran. Terkait dengan tujuan di atas film animasi ini terdiri dari dua jenis jalur pendaftaran yaitu jalur reguler dan jalur beasiswa. Masingmasing jalur tersebut terdiri dari beberapa adegan yang menggambarkan situasi pada saat mahasiswa mendaftar. Adeganadegan tersebut diantaranya yang utama yaitu adegan mahasiswa menuju ke ruang pendaftaran, adegan mahasiswa menuju ke bank untuk melakukan pendaftaran, dan dapat di simpulkan sudah cukup baik.

4. Penelitian yang dilakukan Birawan Yunita Syahfitri berjudul:PERANCANGAN GAME 3D DENGAN KARAKTER PUNAKAWAN SEBAGAI MEDIA PENGENALAN AKSARA JAWA [8] Masih banyak remaja mengalami kesulitan dalam menghafal aksara Jawa. Hal ini dikarenakan terjadinya kurangnya pemanfaatan dan penggunaan akasara Jawa dalam kehidupan sehari-hari, sehingga ilmu tersebut lambat laun akan sirna. Selain itu, aktifitas remaja sekarang ini mayoritas lebih banyak menyenangi bermain game daripada belajar, apalagi game yang banyak disajikan adalah game yang berlatarbelakang dan berkarakter budaya asing. Game 3D pengenalan aksara Jawa ini dirancang sebagai media alternatif pengenalan dan pelestarian kebudayaan Jawa kepada kalangan remaja. Sehingga dapat menarik minat penggunanya. Perancangan game 3D pengenalan aksara jawa ini bertujuan untuk mengetahui cara membuat Game 3D dengan karakter Punakawan sebagai Media pengenalan Aksara Jawa. Proses perancangan dilakukan dengan mengikuti prosedur perancangan prosedural yang bersifat 
deskriptif, yaitu menggariskan langkah-langkah yang harus diikuti untuk menghasilkan produk. Langkahlangkah tersebut diawali dari perusumusan latar belakang masalah, ide, praproduksi, produksi, dan paska produksi game 3D. Data-data berupa gambar aksara Jawa, gambar latar belakang, gambar karakter punakawan, gambar pendukung, serta suara diolah untuk menjadi sebuah game dengan ditambahkan logika pada alur game sesusai dengan sipnopsis yang telah dibuat. Produk yang dihasilkan adalah sebuah game 3D dengan karakter Semar sebagai gambar latarbelakang menu dan picture slide yang ditampilkan pada saat player kalah dan menang dengan alur cerita mengumpulkan aksara Jawa yang terdapat pada peta. Hasil perancangan ini menunjukkan bahwa merancang game animasi berbasis grafis 3 dimensi membutuhkan langkah-langkah yang runtun agar dapat menghasilkan game yang menarik serta memudahkan dalam proses perancangan. Berdasarkan hasil penelitian ini, dapat disarankan agar dilakukan penelitian lanjut misalnya, pengembangan sipnopsis game, animasi karakter, mapping pada objek, serta memperkaya pembendaraan script python untuk menciptakan game yang lebih realistis dengan karakter yang mempunyai AI (artifact intellenge). Kesimpulan : Game ini dirancang sedemikian rupa supaya dapat menarik anak untuk mengenal dan mengetahui karakterk Pewayangan khususnya Punakawan dan Aksara Murni yaitu Aksara Jawa yang dimiliki bangsa Indonesia, dengan visual yang mendukung anak untuk tidak cepat bosan dalam memainkan game ini. Di sini, sangat baik, karena masih ada game yang mengangkat cerita budaya daerah Indonesia.

5. Penelitian yang dilakukan Ismail Ghozali berjudul ANALISIS DAN PEMBUATAN ANIMASI 3D "PENGGABUNGAN FOTO DAN VIDEO DENGAN ANIMASI 3D MENGGUNAKAN 3DS MAX" PADA AGUNG PHOTO [4]. Di samping itu teknik animasi terakhir succesded mengungkap oleh manusia cerdas sejak dalam ribuan lalu. bangunan di teknis tertentu untuk memperluas sampai sekarang animasi sudah tumbuh membuat industri baik di dunia. Dari teknik manual sampai pembuatan animasi digital sekarang ini, animasi sudah menyihir dan keajaiban ribu orang bisa sebagai sarana iklan dan promosi di dunia bisnis. Pengamatan masalah ini adalah penelitian untuk membuat animasi iklan 3 dimensi Agung Photo. Rivalitas di dunia bussnise sekarang ini sangat ketat dan Kekurangan untuk teknik dan metode tertentu mampu bersaing, bertahan dan mengubah dalam dunia bisnis. Dimana Agung Photo media promosi menggunakan tidak maksimal karena hanya menggunakan brosur dan stiker untuk promosi produk \& produk jasa knowleg untuk konsumen. Jadi penelitian ini merupakan membuat analisis tentang kurang tentang produk knowleg dan pelayanan kepada konsumen. Pada kegiatan meneliti, untuk mendapatkan menyelesaikan masalah setuju dengan harapan untuk mengasumsikan tumpukan rumusan masalah sehingga diperlukan yaitu Analisis Dan Pembuatan Animasi 3D "Penggabungan Foto Dan Video Animasi 3d Mencari Google Artikel Menggunakan 3dsMax" pada Agung 
Photo berjudul. Untuk rumusan masalah penulis tentang Bagaimana analysa dan membuat menarik iklan pihak lain, unik dan memiliki nilai komersial dalam bisnis dapat memberikan karakteristik dan daya tarik untuk konsumen. Kesimpulan : Dapat di analisis bahwa banyak kekurangan dalam perancangan iklan animasi ini terutama dalam pembuatan animasi 3D dan visual efeknya yang masih terbatas. Maka dari itu penulis berharap perancangan iklan animasi ini dapat dikembangakan lebih baik.

6. Penelitian yang dilakukan Hendro Saputra Suratinoyo berjudul, CERITA RAKYAT DAERAH MINAHASA IMPLEMENTASI SHORT FILM ANIMASI 3D,[11] Multimedia bukan hanya menyediakan banyak teks, melainkan juga dengan menghidupkan teks yang di sertai bunyi, gambar, musik, Animasi dan video. Cerita rakyat daerah minahasa : Implementasi short film animasi 3D, didasarkan pada ide dan alur cerita yang mendukung kegiatan produksi film animasi 3D, produksi film animasi 3D menggunakan kerangka penelitian film pendek animasi 3D. Software yang digunakan: blender, audacity, avidemux. Objek-objek yang telah selesai dibuat akan ditata sesuai kebutuhan adegan, animasi dilakukan dengan proses rigging serta skinning pada objek karakter. Animasi yang telah dibuat akan dirender, render berupa potongan-potongan adegan dalam bentuk video.Untuk jalannya audio disesuaikan dengan jalannya video. Setelah semua potongan potongan adegan video sudah dilengkapi dengan audio. Penggabungan adegan - adegan video, menghasilkan keluaran video animasi 3D secara keseluruhan. kesimpulan : Dalam pembuatan film pendek animasi 3 demensi cerita rakyat ini tidak saja diperlukan kemampuan penguasaan program, tetapi ide dan imajinasi juga harus lebih di kembangkan agar bias menciptakan animasi yang lebih terasa di hati penonton. Dan Dalam proses pembuatan sebuah film animasi sebaiknya dikerjakan secara tim agar bisa mendapatkan hasil yang maksimal dan juga bisa menghemat waktu dalam proses pengerjaan dari tahap awal sampai pada tahap akhir pembuatannya,

7. Penelitian yang dilakukan Yosep Irawan Hindriatmoko berjudul IMPLEMENTASI SIMULATION UNTUK PEMBUATAN FILMANIMASI 3D PADA SOFTWARE 3DS MAX Penulisan skripsi ini membahas tentang membuat film animasi 3D dengan teknik Crowd Simulasi. Tahapan ambil adalah dari pra produksi sampai pasca produksi dan animasi 3D dalam pembuatan film, terutama untuk pembuatan model tiga dimensi dari karakter yang terdapat teknik Crowd Simulasi yang berfungsi untuk memfasilitasi model yang seorang artis dalam membuat tekstur model karakter 3D atau tekstur. Film animasi pemodelan dibuat dengan karakter 3D, diikuti oleh texturing dan rigging setelah pemodelan selesai diberikan yang berfungsi untuk mengontrol pergerakan karakter yang dapat menghidupkan dan tahap akhir untuk memberikan pencahayaan atau lampu untuk menerangi lokasi yang kemudian siap untuk rendering avi Format. Katak pembuatan film ini diharapkan animasi dengan Crowd 
Simulasi mungkin berguna untuk semua pembaca, terutama bagi mereka yang akan melakukan pembuatan film 3D Animasi. kesimpulan : Dari penelitian yang dilakukan dapat dilihat bahwa dalam proses pembuatan film animasi 3D dengan menggunakan teknik Crowd akan dapat mempermudah dan mempercepat seorang animator dalam proses pembuatan film animasi 3D, sehingga akan mempersingkat waktu dalam proses produksi. Akan tetapi kelemahan menggunakan teknik Crowd pada film animasi 3D ini ketika burung naga sedang terbang dari titik awal menuju ke titik akhir atau tujuan hanya dapat .

8. Penelitian yang dilakukan Imam Setiawan berjudul, PEMBUATAN IKLAN 3D "DAGADU" SEBAGAI MEDIA PROMOSIBERBASIS MULTIMEDIA, [5] Penulis membuat bahan penulisan diperoleh dari pengamatan di PT. DAGADU perusahaan kemeja di Jogja. Setelah diperoleh hasil pengamatan PT.DAGADU, PT.DAGADU tidak memiliki iklan produk DAGADU informasi dimedia televisi. Dengan penciptaan iklan 3D Dagadu tentu saja akan memudahkan pemasaranproduk yang lebih efektif, merancang iklan untuk penulis untuk menyusun video yangiklan menampilkan produk dari DAGADU. 3D Iklan Dagadu yang membuat lebih mudah bagi konsumen untuk melihat produk dan memudahkan PT.DAGADU dalam memasarkan produk dan dapat menghasilkan gambar 3D dari produk melalui iklan yang kita buat. Kesimpulan : Dalam penelitian ini, penulis kurang mengangkat, editing gambar dengan menggunakan adobe photoshop, step by stepnya kurang dan penjabaran yang di rasa kurang, yang di bahas di atas, hanya proses $3 \mathrm{~d}$.

9. Penelitian yang dilakukan Moh. Ali Anwar berjudul PERANCANGAN FILM ANIMASI "BUDI" UNTUK MENANAMKAN BUDI PEKERTIKEPADA ANAK-ANAK [1]

Film animasi digunakan sebagai tempat terjadinya proses pembentukan identitas diri anak, maksudnya adalah dalam kesehariannya anakanak dimungkinkan akan meniru prilaku seperti tokoh kartun tersebut. Masa anak-anak merupakan titik awal perkembangan dan pertumbuhan manusia yang sangat penting. Pada masa kanak-kanak yaitu pada anak usia 6 sampai 9 tahun, mereka dapat melakukan berbagai tugas yang kongkrit sehingga mudah terpengaruh terhadap adanya media-media yang dapat berdampak negatif .Maka diperlukan suatu inovasi baru yang dapat menjadikan media hiburan juga sebagai media penyampaian pesanpesan untuk menanamkan budi pekerti, yaitu dengan membuat film animasi 3 dimensi.Perancangan ini menggunakan metode prosedural yang bersifat deskriptif.Model yang digunakan dalam perancangan ini adalah Model perancangan $M$. Yoshioka.Selanjutnya dari model tersebut, dapat ditentukan sistematika perancangan film animasi dengan penyesuaian menurut Issac Kerlow dengan alur praproduksi, produksi, dan pascaproduksi.kesimpulan : Waktu yang singkat. Ini menimbulkan kurang maksimalnya pengerjaan animasi ini.Ketersediaan sarana mempengaruhi perancangan film animasi.Animating dengan partikel 
yang banyak akan memerlukan proses rendering lebih lama. Hal ini dapat diatasi dengan menyederhanakan objek, atau yang biasa dikenal dengan low poly, serta penggunaan teknik maping yang sederhana.

10. Penelitian yang dilakukan Budi Setiawan berjudul "RANCANG BANGUN PEMBUATAN ANIMASIIKLAN LAYANAN MASYARAKA "MASA DEPAN TANPA NARKOBA"[12]Tujuan dalam penulisan ini adalah membuat iklan animasi 3D berupa iklan layanan masyarakat yang menarik. Kegiatan yang dilakukan sebelum proses pengerjaan animasi adalah menganalisis kebutuhan pengerjaan dan proses pengerjaan animasi iklan. Tahap pengerjaan terbagi menjadi tiga, yaitu tahap pra produksi yang terbagi menjadi fase ide/cerita, penulisan naskah dan pembuatan storyboard, tahap produksi yang terbagi menjadi fase modeling, texturing, rigging, animasi, lighting dan rendering, serta tahap paska produksi yang terbagi menjadi fase compositing, koreksi warna dan hasil akhir. Fase modeling, animasi dan rendering membutuhkan waktu pengerjaan yang lebih lama dibandingkan dengan fase lainnya. Hasil akhir dari proses animasi ini berupa file video dengan format AVI. Pembuatan iklan animasi layanan masyarakat ini diharapkan mampu Mengingatkan masyarakat tentang bahayanya pengguna narkoba dengan menggunakan iklan animasi 3 dimensi kesimpulan : Untuk menghasilkan animasi 3D yang lebih baik, diperlukan perangkat yang lebih baik, agar pengerjaan dapat lebih mudah dan lebih cepat. Dibutuhkan pula tim ahli untuk pada masing-masing bidang animasi seperti, modeling, texturing, rigging, compositing dan lain-lain agar hasil animasi 3D dapat lebih maksimal. Untuk dapat mengerjakan proyek animasi yang lebih baik, waktu proyek yang lebih lama akan sangat membantu dalam proses pengerjaan.

\section{PEMBAHASAN}

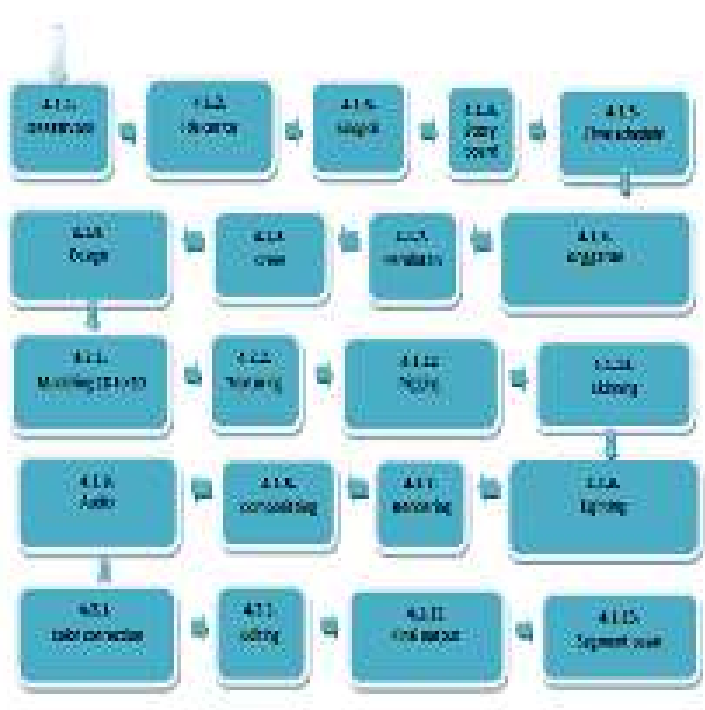

Gambar 1 : Bagan Preproduction sampai dengan postproduction

Storyboard

Storyboard berupa sket gambar yang dilengkapi dengan petunjuk atau catatan pengambilan gambar untuk kebutuhan pembuatan video. Selama proses praproduksi, perencanaan yang berhubungan dengan visualiasasi yang akan dibuat membutuhkan Storyboard sebagai media bantuannya.

\section{SCENE I:}

Menampilkan adegan fun meriah pembukaan 


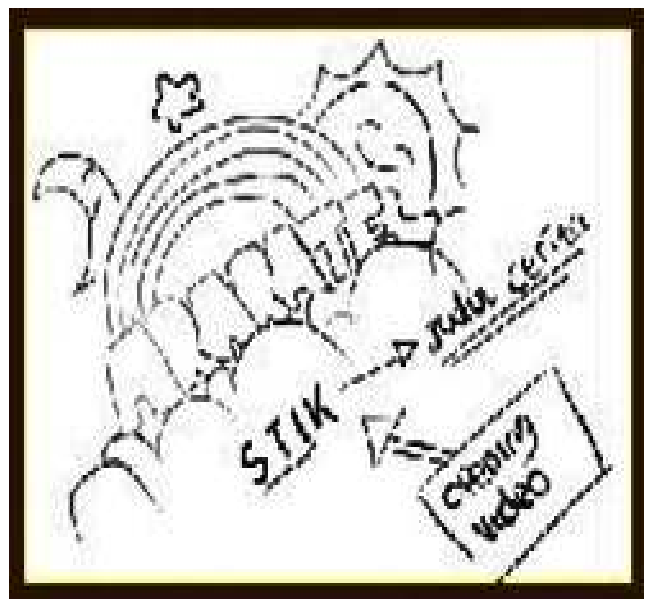

Gambar 2.adegan fun meriah pembukaan

SCENE II:

Menampilkan adegan kamera masuk dari atas awan, awan out frame zoom sedikit kepada 2 character utama

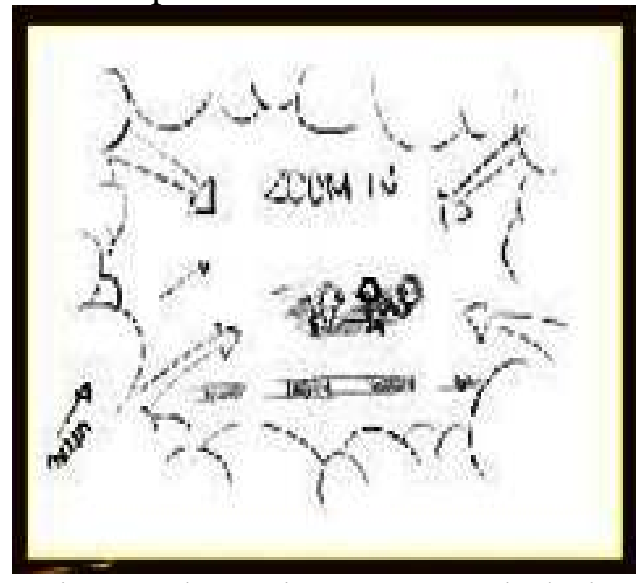

Gambar 3.adegan kamera masuk dari atas awan, awan out frame zoom sedikit kepada 2 character utama

SCENE III:

Menampilkan adegan kamera mereka sedang menikmati sate

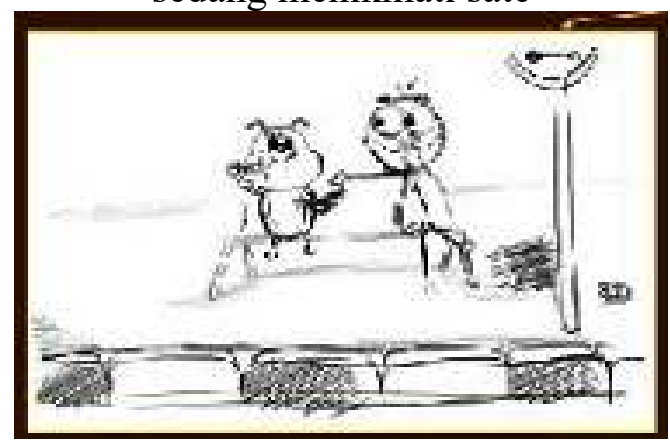

Gambar 4.adegan kamera mereka sedang menikmati sate

\section{Design} untuk penyempurnaan story board,mempertegas karakter yang akan di buat semua itu sebuah design yang harus di fiks kan sebelum masuk tahap produksi,menetapkan design untuk seluruh konsep dimulai dimatangkan disini agar sebelum masuk produksi sudah matang terlebih dahulu.

Pertama-tama Design awal adalah Design tokoh karakternya disini Tokohnya ada Dua yaitu Seekor kutu Dan seekor nyamuk yang sudah di rubah dari bentuk asli, konsepnya pula dirubah dari yang mengerikan menjadi menggemaskan dan kutu disini diciptakan menjadi imut,lucu,dan menyenangkan lalu dari segi warna di gunakan warna orange karena warna orange warna yang sangat menarik memiliki sifat menyenangkan maka dari itu sangatlah cocok jika kutu ini di beri warna orange, dan dari bentuknya badannya pendek dan kepalanya besar bisa di sebut dengan chibi.

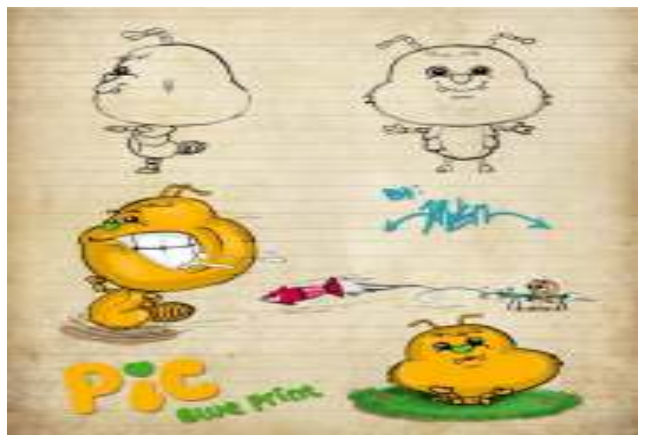

Gambar 5. Design karakter Pic 
Kemudian Design konsep karakter ito (nyamuk) di buat dengan gaya yang menyebalkan menggemaskan di warnai dengan konsep ungu yang mempunyai sifat lebih dengan ke sifat menyebalkan usil dst, ito bentuknya lebih tinggi dari pic dan kepalanya juga besar idungnya lancip buntutnya meman jang kebelakang.

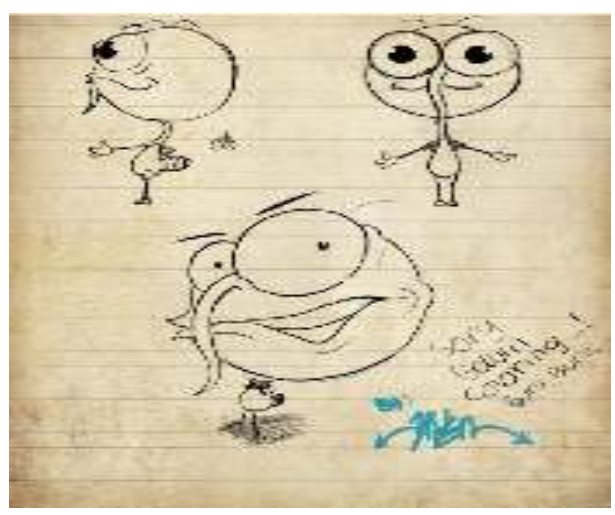

Gambar 6. Design karakter ito

Selain membuat konsep karakternya di episode pertama ini di buat juga konsep design senjata pletokan bambunya

\section{Teksturing}

Dalam dunia visual, texturing adalah proses pemberian karakteristik permukaan pada objek. Maksud dari karakteristik adalah termasuk pewarnaan, kilauan, dan lainnya. Pada umumnya teksturing adalah pemberian warna pada permukaan objek atau pengecatan, walaupun ada proses yang mengubah geometri objek. Dalam software seperti 3DSMax dan Blender, untuk menambahkan tekstur pada objek, kita bisa menggunakan tools Map.

Teksturing sangat penting dalam desain 3D atau animasi, karena dengan teksturing inilah objek akan terlihat menjadi hidup. Karena jika hanya dengan warna biasa, suatu objek tidak akan terlihat hidup, namun dengan tekstur kita bisa mengubah gambar biasa menjadi hidup. Dengan adanya tekstur juga bisa mengubah objek yang sebenarnya kurang halus menjadi terlihat lebih halus, jika dibandingkan dengan objek tanpa tekstur.

Terdapat dua masalah utama yang berhubungan dengan tekstur yaitu :

\section{a. Segmentasi Tekstur (Texture segmentation)}

Merupakan masalah yang memecah suatu citra ke dalam beberapa komponen dimana tekstur dianggap konstan. Segmentasi tekstur melibatkan representasi suatu tekstur, dan penentuan dasar dimana batas segmen akan ditentukan.

b. Sintesis Tekstur (Texture synthesis)

Berusaha untuk membangun region tekstur besar yang berasal dari contoh citra kecil yang ada. Dengan menggunakan contoh citra akan dibangun model probabilitas tekstur tersebut, dan kemudian menggambarkannya pada model probabilitas untuk menentukan tekstur citra. 


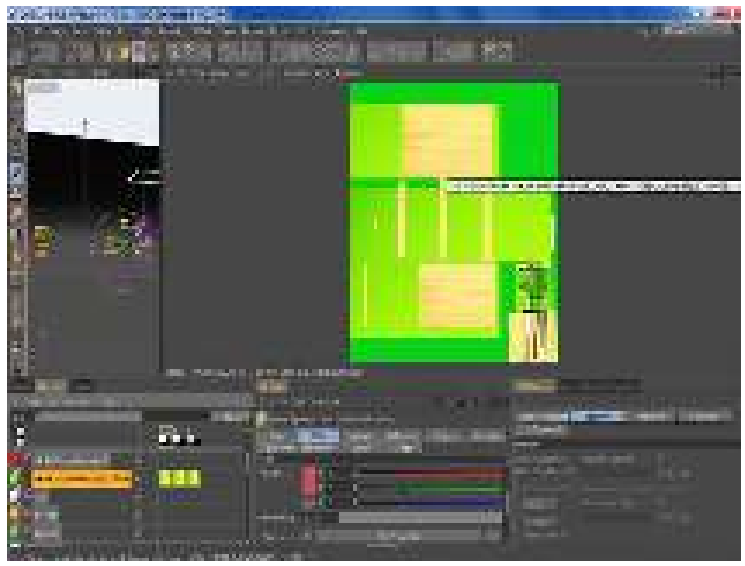

Gambar 7.texturing dari pletokan bambu pic

\section{Rigging}

Rigging adalah pemberian struktur tulang pada objek 3 dimensi, agar ke depannya objek 3 dimensi tersebut dapat digerakkan melalui tulang tersebut.Rigging merupakan hal yang penting dan bila terjadi bentuk yang tidak simetris pada animasi kita, berarti itu adalah kesalahan pada saat rigging.

Meskipun kemungkinan besar itu merupakan kesalahan proses modelling dimana objek $3 \mathrm{~d}$ tersebut tidak sesuai topologi pada umumnya sehingga mengakibatkan tidak simetris.

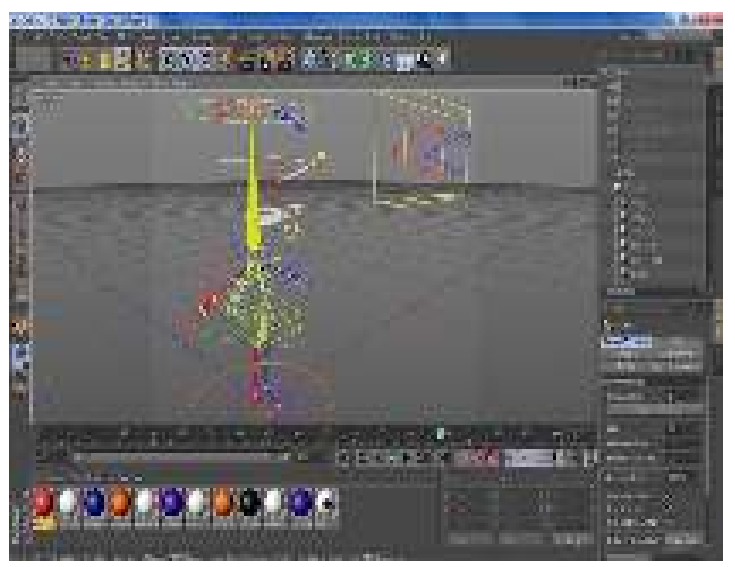

Gambar 8. Rigging ito

\section{Skinning}

Skinning ialah teknik penyatuan sebuah tulang dengan sebuah objek, disana kita bisa mengatur kepekaan antara tulang dengan objek,yang dimana fungsinya membuat character bisa di animate untuk animatornya nanti.

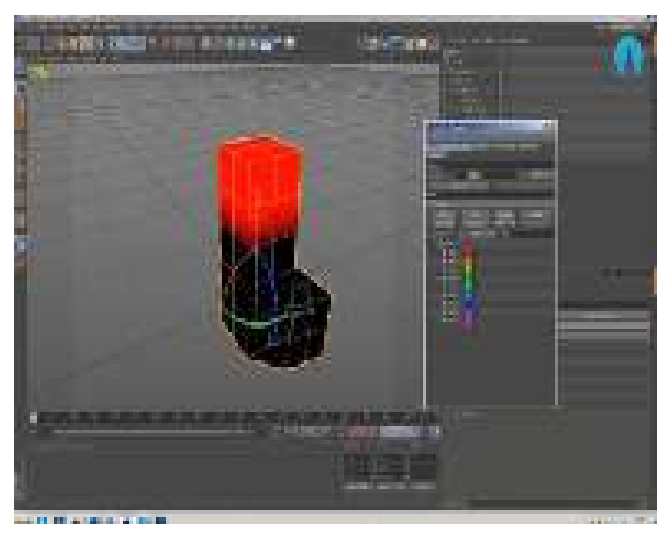

Gambar 9. Skinning

\section{Lighting}

Teori pencahayan di dalam cinema4d sedikit berbeda dengan pencahayaan nyata, apa bila di alam nyata cahaya akan secara otomatis memberikan bayangan, maka di dalam cinema4d cahaya tidak langsung memunculkan bayangan sebelum kita aktifkan mode bayangan. Dan ada beberapa 
perbedaan lainnya.Jenis cahaya standard di dalam cinema4d tersedia dua tipe cahaya, yaitu standard dan photomatric.Pencahayaan tipe standard adalah tipe pencahayaan yang biasa di gunakan untuk bermacam keperluan.Dan metode pengaturannya juga secara manual, artinya kita harus melakukan pengaturan cahaya secara detail agar menghasilkan efek yang realis.

Ada 4 jenis cahaya yang terdapat dalam standard lights, Omni Pencahayaan yang di hasilkan oleh omni light biasanya cenderung

merata ke semua area, karena onmi memiliki

bentuk seperti layaknya cahaya matahari, yaitu berasal dari satu titik dan memancar kesekelilingnya.

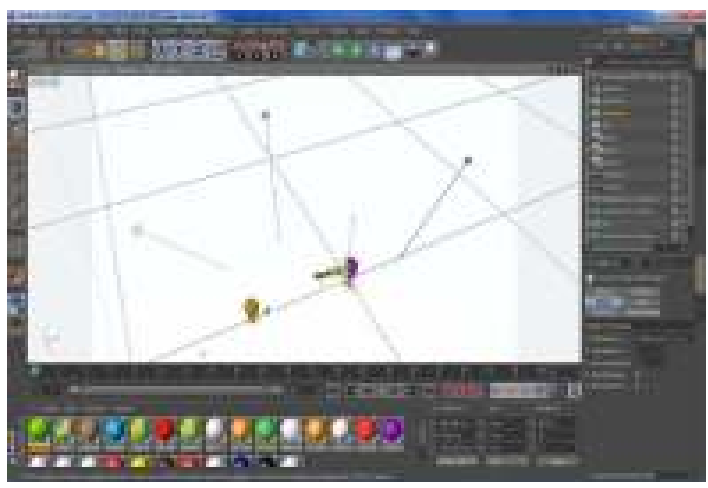

Gambar 10.lighting menggunakan keyLight,FillLight,BackLight

Rendering

3D Rendering merupakan proses untuk membentuk sebuah gambar dari sebuah model yang dibentuk oleh perangkat lunak animasi, model tersebut berisi data geometri, titik pandang, tekstur dan cahaya yang diperlukan untuk membuat gambar yang utuh.3D Rendering merupakan proses yang sangat penting dan telah digunakan untuk berbagai macam penggunaan, seperti program permainan komputer, efek spesial pada film dan program simulasi.Hasil Proses 3D Rendering .
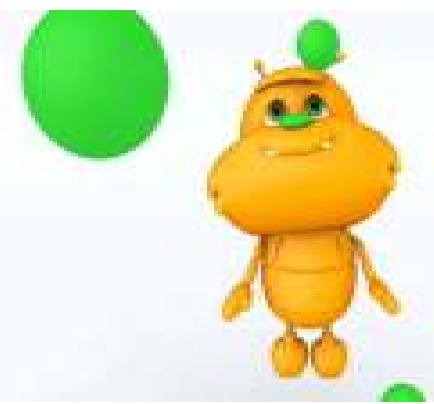

\section{Gambar 11. Hasil Rendering}

Dalam menyalurkan informasi, PT. Movio Screen membangun media promosi dengandesign karakter animasi 3duntukmenunjang promosi pada PT. Movio Screen serial ini mampu menjadi terobosan baru untuk mengembangkan sayap perusahaan, dan menambah citra perusahaan. Adapun tujuan lainnya adalah dapat memperkenalkan animasi Indonesia hingga go International.

Ide Cerita

Animasi serial ini bernama Ararateul di angkat dari bahasa sunda yang artinya gatal karena di dalamnya teradapat dua tokoh yang sejenis makhluk serangga yang membuat manusia bisa kegatalan tapi mereka berperilaku sebaliknya membuat semua orang bisa terhibur dengan kehadirannya.

Dua tokoh utama yang bernama Pic dan Ito . Pic adalah seekor kutu yang baik hatinya, polos,lucu, konyol tetapi pintar,sayang kepada sesama, 
sedangkan Ito adalah nyamuk yang banyak akal dan sedikit arogan,menyebalkan tetapi tak bisa lepas dari sosok pic di hatinya. Mereka berdua adalah sahabat, mereka selalu membuat aksi-aksi yang seru dan menggemaskan, aksiaksi mereka di dukung dengan konsep alat lokal dari budaya indonesia yang selalu menemani aksi-aksinya tersebut sebagai contoh yang epside pertama ini yang di angkat alatnya adalah pletokan bambu yang sudah mahsyur di indonesia sebagai salah satu alat-alat budaya.

Untuk mendapatkan cerita lebih detailnya di epsiode pertama di masukan di dalam sinopsis.

Sinopsis

Diceritakan di bawah langit ararateul terdapat sebuah halte menunggu bus terdapatlah dua sahabat yang sedang asik dalam menunggu bus yang sedang mereka tunggu lalu pic supaya tidak jenuh dia memakan sebuah sate kemudian ito sahabatnya tergiur dengan sate yang sedang di nikmati oleh pic dengan hati yang baik pic menawarkan sate tersebut kepada ito dengan sangat senang hati ito menerimanya.

Tiba-tiba di bawah langit ararateul terlihat sinar yang menarik perhatian mereka berdua sehingga mereka lupa akan asyiknya makan sate yang lezat tadi, ternyata yang jatuh sebuah bambu ajaib dari langit araratuel yang dapat di gunakan untuk membuat benda-benda, mereka berdua dengan semangatnya ingin mengambil bambu itu dengan saling berebutan lalu patahlah bambu tersebut terbagi dua karena pic dan ito makhluk yang kreatif mereka ingin merancang sebuah bentuk dari bambu tersebut.

\section{KESIMPULAN}

1. Jadi jenis media informasi yang secara Audio visual dapat menarik perhatian dan menunjang promosi pada PT. Movio Screen adalah animasi 3d serial karena lebih menarik dan banyak digemari oleh hampir semua kalangan ,terutama adalah anak-anak, sehingga dapat menjadi salah satu media informasi yang baik. Dari perancangan media yang dihasilkan, target yang dinginkan adalah animasi $3 \mathrm{~d}$ serial ini mampu menjadi terobosan baru untuk mengembangkan sayap perusahaan, dan Membentuk citra produk di mata konsumen sesuai dengan yang diinginkan, Maka dari itu manfaat yang akan di capai melalui animasi serial dalam bentuk animasi 3D adalah Meningkatkan citra PT. Movio Screen, Dapat menjadi sarana promosi dan informasi PT. Movio Screen dan bisa dijadikan portofolio pada PT. Movio Screen, Membedakan serta mengunggulkan produk dibanding produk pesaing

\section{DAFTAR PUSTAKA}

1. Ali, Anwar Moh, Film Animasi "Budi" Untuk Menanamkan Budi Pekerti Kepada Anak-Anak, Universitas Negeri Malang”. Malang 
2. Djalle, Zaharuddin. Purwantoro, Edi. Dasmana, Demi. "3D Animation Using $3 D$ StudioMax". Bandung: Penerbit Informatika Bandung

3. Fernandes, Ibiz "Macromedia Flash Animation \& Cartooning: A creative Guide," Fernandez McGrawHill/Osborn", California,

4. Ghozali, Ismail berjudul Analisis Dan Pembuatan Animasi 3d "Penggabungan Foto Dan Video Dengan Animasi 3d Menggunakan 3ds Max" Pada Agung Photo. Sekolah Tinggi Manajemen Informatika Dan Komputer Amikom Yogyakarta

5. Imam Setiawan berjudul, "Pembuatan Iklan 3d "Dagadu" Sebagai Media Promosi Berbasis Multimedia", Sekolah Tinggi Manajemen Informatika Dan Komputer Amikom Yogyakarta

6. Immaniar, Dewi, Sudaryono dan Dwi Ayu Ningrum. "Enriching Media Merchandise Sarana Penunjang Promosi Studi Kasus Pada BookStore". Tangerang: Jurnal CCIT.

7. Indah, Paramitha Apriliana "Animasi 3d Kisah Ayu Intan Permani”, Sekolah Tinggi Manajemen Informatika Dan Computer STMIK Amikom Purwokerto

8. Irawan, Hindriatmoko Yosep, "Implementasi Crowd Simulation
Untuk Pembuatan Film Animasi 3d Pada Software 3ds Max", Sekolah Tinggi Manajemen Informatika Dan Komputer Amikom Yogyakarta

9. Maimunah, Lusyani Sunarya dan Nina Larasati.. "Media Company Profile Sebagai Sarana penunjang Informasi Dan Promosi”. Tangerang: Jurnal CCIT.

10. Nugraha,Moch Adhi, "Perancangan Prosedur Kkp Dan Ta/Skripsi Dengan Menggunakan Media Audio Visual Pada Perguruan Tinggi Raharja, STMIK Raharja

11. Saputra, Suratinoyo Hendro," Cerita rakyat daerah minahasa : "implementasi short film animasi 3d", Kampus UNSRAT Bahu, Manado

12. Setiawan, Budi "Rancang Bangun Pembuatan Animasi Iklan Layanan Masyaraka "Masa Depan Tanpa Narkoba" STMIK GI MDP. Palembang

14. Tjiptono, Fandy, "Strategi Pemasaran". Yogyakarta Andi

15. Waskita, Beatrice, film animasi "pendaftaran mahasiswa baru" Menggunakan 3ds max : Animation effects, lightning, and shooting , Universitas Gunadarma Depok. 